Article

\title{
Assessment on the Soil Retention Service of Water Erosion in the Nile River Basin Considering Vegetation Factor Variance from 1982 to 2013
}

\author{
Hua Liu ${ }^{1,2}$, Wenwu Zhao ${ }^{1, *}$ and Yanxu Liu ${ }^{1}$ (D) \\ 1 State Key Laboratory of Earth Surface Processes and Resource Ecology, Faculty of Geographical Science, \\ Beijing Normal University, Beijing 100875, China; liuhua322@yeah.net (H.L.); yanxuliu@bnu.edu.cn (Y.L.) \\ 2 College of Geoscience and Surveying Engineering, China University of Mining and Technology, \\ Beijing 100083, China \\ * Correspondence: zhaoww@bnu.edu.cn
}

Received: 26 June 2020; Accepted: 13 July 2020; Published: 16 July 2020

\begin{abstract}
Water erosion has negative effects on agricultural productivity in Africa. The cover management factor ( $\mathrm{C}$ factor) related to vegetation is the most influential parameter in the estimation of water erosion and reflects key interrelated cover and management information on the soil retention service of water erosion. However, the estimations of $C$ factor on a large-scale display large differences. The Nile River Basin has suffered severe water erosion for several decades, while the soil retention service of water erosion from vegetation is still unclear. This study assesses the spatiotemporal change in soil retention service in the Nile River Basin from 1982 to 2013, based on the Revised Universal Soil Loss Equation (RUSLE) model. The comparison of six kinds of estimation methods showed that four methods could be used, whereas the other two were inappropriate. The average annual soil retention service based on the $C$ factor variance ranged from 934.08-1240.56 $\left(\mathrm{t} \mathrm{ha}^{-1} \mathrm{y}^{-1}\right)$, and spatially increased from south to north. The area of significant increasing and decreasing tendencies were $1.31 \times 10^{4}-1.94 \times 10^{5} \mathrm{~km}^{2}$ and $5.68 \times 10^{3}-3.81 \times 10^{4} \mathrm{~km}^{2}$, respectively. These results provide a reference for the selection of $C$ factor methods and spatiotemporal evidence of the soil retention service of water erosion in the Nile River Basin.
\end{abstract}

Keywords: water erosion; C factor; soil retention service; mapping; tendency; Nile River Basin

\section{Introduction}

The acceleration of water erosion has plagued human beings since the dawn of settled agriculture [1]. Approximately $50 \%$ of the population heavily relies on local agriculture for food in Africa, which has led to extreme water erosion with poor management [2]. With limited resources to invest in soil retention service of water erosion management, the continued pressure on resources further aggravates land degradation due to water erosion, soil nutrient mining, deforestation and loss of biodiversity [3]. It is estimated that the range of agricultural yield reductions varied from $2 \%$ to $40 \%$ from 1970 to 1990, and the reductions in Africa by the year 2020 could reach 16.5\% [4]. Because water erosion is a growing threat that affects the livelihoods of humans in Africa and is a threat to any future agriculture, the spatiotemporal change in the soil retention service of water erosion requires detailed tracking $[5,6]$. Accordingly, providing scientific guidance for the maintenance and management of the soil retention services of water erosion and, subsequently, enhancing this ecosystem service require a credible spatiotemporal assessment $[7,8]$, which can help locate areas where water erosion is drastic and where the soil retention services need to be enhanced [9].

Revised Universal Soil Loss Equation (RUSLE) models are effective methods for evaluating the soil retention service of water erosion on a large scale $[10,11]$. A RUSLE model requires data on climate, 
topography, soil and vegetation [12]. Among these parameters, vegetation affects nutrient removal and, in turn, plant productivity, which is closely related to the soil retention service intensity [13]. Thus, the vegetation growth plays a positive role in providing the soil retention service and preventing water erosion [14,15], and it refers to the cover management (C) factor in the RUSLE model $[16,17]$. Estimating the cover management factor ( $\mathrm{C}$ factor) by specific local selection criteria parameters is therefore crucial for the credible assessment of water erosion and soil retention service [18].

The traditional method used to estimate the $C$ factor value is the soil loss ratio, which is an estimate of the ratio of water erosion under actual conditions to losses occurring under a reference condition. The soil loss ratio calculation contains five subfactors (prior land use, canopy cover, surface cover, surface roughness and soil moisture) [19]. Each soil loss ratio value is weighted by the fraction of rainfall and runoff erosivity associated with the corresponding time period, and these weighted values are combined into an overall C factor value [20]. However, both methods are based on field experiments in which acquiring relative data for estimating the $C$ factor is difficult to obtain in areas where little recorded data are available, such as Africa. Therefore, the detection of changes in the C factor based on remote sensing imagery is necessary in the analyses of the spatiotemporal changes of water erosion [21,22].

In the cover classification methods, $\mathrm{C}$ factor values can be assigned to cover types that were originally categorized as land cover maps [23]. For example, a spatial distribution map of $C$ factor values in the Yanhe watershed on the Loess Plateau of China has been drawn in combination with $C$ factors for other land use types [24]. This type of method can provide rapid $C$ factor values but cannot take the detailed temporal variance in vegetation into account. The Normalized Difference Vegetation Index (NDVI) is one of the primary indices used for spatiotemporal vegetation monitoring and assessment [25], and forms different algorithms in C Factor calculations. Because various $C$ factor evaluation methods are available, the $C$ factor should be estimated with different methods at the same scale to improve the credibility of the assessment.

The Nile River Basin is a prominent farming community in Africa in which people rely on agricultural production for a living, and also has historically suffered from land degradation [26]. The main objective of this study is to estimate the spatiotemporal change in the soil retention service of water erosion based on the $C$ factor variance in the Nile River Basin from 1982 to 2013. The objectives of this study are as follows: (a) to select effective $C$ factor methods based on the land cover and NDVI data; (b) to assess the spatiotemporal characteristics of soil retention service of water erosion based on the RUSLE model; and (c) to quantify the tendency for changes in the soil retention service of water erosion with nonparametric linear regression analysis.

\section{Materials and Methods}

\subsection{Study Area}

The study area is a river catchment that flows through eastern and northern Africa and is located in the northeastern part of Africa (Figure 1). The total area of the Nile River Basin is 3.25 million km², accounting for $10 \%$ of the total area of Africa, and contains parts of Uganda, Egypt, Sudan and Ethiopia. The Nile River Basin is located from $5^{\circ} \mathrm{N} 33^{\prime} \mathrm{E}$ to $15^{\circ} \mathrm{N} 39^{\prime} \mathrm{E}$, and the highest altitude is $5000 \mathrm{~m}$. The Nile River, with a total length of $6670 \mathrm{~km}$, is the world's longest river and contains the Blue Nile, with a length of $1450 \mathrm{~km}$, and the White Nile. The Blue Nile and the White Nile join in Khartoum to form the Nile River. The river flows northeast and continues its course up to Egypt, where it enters Lake Nasser; then, the river flows further downstream to enter the Nile Delta before reaching the Mediterranean Sea [3]. The Blue Nile River flows south from Lake Tana and then west across Ethiopia and northwest into Sudan [27]. The climate of the Nile River Basin is obviously different from north to south and belongs to the savanna and tropical desert climates; for example, the Ethiopian highlands in the southern part of the basin are located in an important rainfall center. The climate is wet, with 
the average annual rainfall ranging from 1000 to $2000 \mathrm{~mm}$, whereas that of the Sudan border is dry, with the average annual rainfall ranging only from 25 to $200 \mathrm{~mm}$.

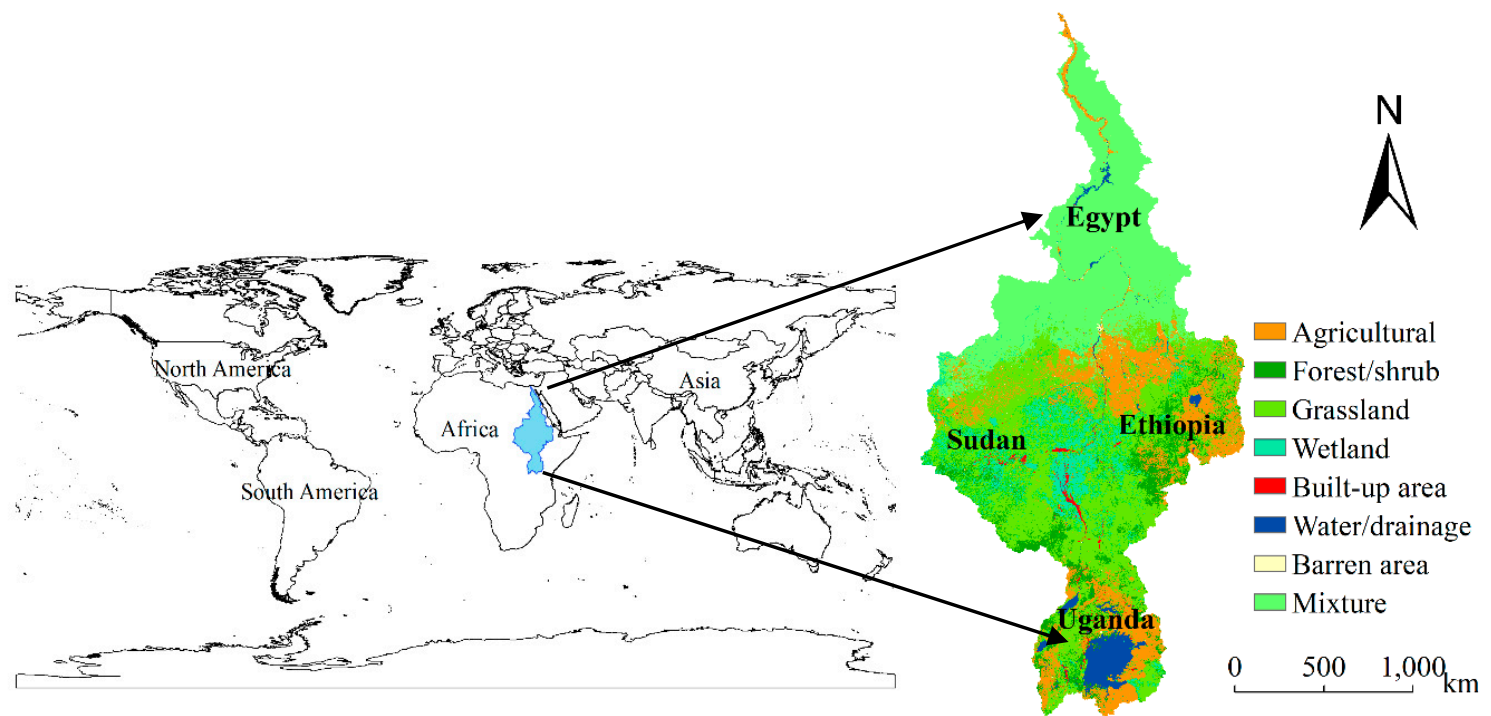

Figure 1. Location and land use map of the study area.

\subsection{Data Sources}

The datasets in the soil retention service of water erosion assessment included the NDVI, land use and cover types, soil properties, slope and precipitation. The NDVI is used in the Global Inventory Modeling and Mapping Studies (GIMMS) (https://ecocast.arc.nasa.gov/data/pub/gimms/3g.v0/), and the time series was from 1982 to 2013, with a time resolution of 15 days and a spatial resolution of $8 \mathrm{~km}$. The GIMMS NDVI3g eliminates the effects of volcanic eruptions, solar elevation angles and sensor sensitivity over time. In this study, considering the advantage of the half-month resolution, both the yearly NDVI and the monthly NDVI were calculated. The yearly NDVI was set as the average of the monthly NDVI values when NDVI > 0.1. Then, we estimated the $C$ factor based on the yearly NDVI. The land use and cover types are derived from the European Space Agency (ESA) Climate Change Initiative (CCI) (http://maps.elie.ucl.ac.be/CCI/viewer/index.php) version 2.0 with a resolution of $300 \mathrm{~m}$ from 1992 to 2013, and are grouped into eight land categories according to the United Nations Food and Agriculture Organization (FAO) land classification, including agriculture area, forest/shrub, grassland, wetland, built-up area, water/drainage area, barren area and mixture (shrub land/sparse vegetation).

The soil properties were derived from the Harmonized World Soil Database v1.2, which has a 30" resolution production (http://www.fao.org/soils-portal/soil-survey/soil-maps-and-databases/en/). The slopes were derived from the Shuttle Rader Topography Mission (SRTM) digital elevation model (DEM), which has a resolution of $90 \mathrm{~m}$ (http://www.gscloud.cn). The precipitation was derived from the National Oceanic and Atmospheric Administration (NOAA) (https:/gis.ncdc.noaa.gov/maps/ncei/cdo/ daily), and the time series was from 1982 to 2013 at daily level. Similarly, all datasets were resampled to an $8-\mathrm{km}$ resolution using the average value after the factor calculation in the RUSLE (Table 1). 
Table 1. Quantitative numbers on all Revised Universal Soil Loss Equation (RUSLE) factors.

\begin{tabular}{|c|c|c|c|}
\hline RUSLE Factors & Data Resolution & Resolution & Quantitative Methods \\
\hline C factor & $\begin{array}{l}\text { NDVI }(8 \mathrm{~km}) \text {, } \\
\text { land use and cover }\end{array}$ & $\begin{array}{l}8 \mathrm{~km} \\
300 \mathrm{~m}\end{array}$ & Table 2 for details. \\
\hline $\mathrm{R}$ factor & Precipitation & Daily & Richardson model [28] \\
\hline $\begin{array}{l}\mathrm{L} \text { factor } \\
\mathrm{S} \text { factor }\end{array}$ & Slope & $90 \mathrm{~m}$ & $\begin{array}{l}\text { Grading method based } \\
\text { on slope [29-31] }\end{array}$ \\
\hline $\mathrm{K}$ factor & Soil properties & $30^{\prime \prime}$ & EPIC model [32] \\
\hline
\end{tabular}

\subsection{Estimation of Water Erosion and Soil Retention Service}

The RUSLE was designed to predict the long-term average water erosion due to runoff from specific field areas in specified cropping and management systems. The soil retention service is equal to the potential water erosion minus the actual water erosion. The RUSLE estimates the annual water erosion and soil retention service as follows:

$$
\begin{gathered}
\mathrm{A}_{\mathrm{r}}=\mathrm{R} \times \mathrm{K} \times \mathrm{L} \times \mathrm{S} \times \mathrm{C} \times \mathrm{P} \\
\mathrm{A}_{\mathrm{p}}=\mathrm{R} \times \mathrm{K} \times \mathrm{L} \times \mathrm{S} \\
\mathrm{A}_{\mathrm{c}}=\mathrm{A}_{\mathrm{p}}-\mathrm{A}_{\mathrm{r}}=\mathrm{R} \times \mathrm{K} \times \mathrm{L} \times \mathrm{S} \times(1-\mathrm{C} \times \mathrm{P})
\end{gathered}
$$

where $A_{r}$ is the estimated actual water erosion per year $\left(t h a^{-1} y^{-1}\right), A_{p}$ is the estimated potential water erosion per year $\left(t \mathrm{ha}^{-1} \mathrm{y}^{-1}\right), \mathrm{A}_{\mathrm{c}}$ is the estimated reduced water erosion per year (evaluated soil retention service amount) ( $\left(\mathrm{ha}^{-1} \mathrm{y}^{-1}\right), \mathrm{R}$ is the runoff factor (MJ mm ha $\left.\mathrm{h}^{-1} \mathrm{~h}^{-1} \mathrm{y}^{-1}\right)$, which expresses the erosivity occurring from rainfall and runoff at a particular location, $\mathrm{K}$ is the soil erodibility factor ( $\mathrm{t}$ ha $\mathrm{h} \mathrm{ha} \mathrm{M}^{-1} \mathrm{MJ}^{-1} \mathrm{~mm}^{-1}$ ), LS is the slope length and steepness factor, $\mathrm{C}$ is the cover management factor and $\mathrm{P}$ is the support practice factor. Deriving appropriate $\mathrm{P}$ factor values by remote sensing is difficult; thus, this study used a $P$ factor value of 1 . Since there are no specific methods for estimating these factors in this study, we selected the algorithms that were applied in global or African studies to estimate them [33,34].

According to soil retention service research in Africa and in the sub basin of the Nile River Basin, we divided the soil retention service of the Nile River Basin into five grades. The soil retention service $\left(\mathrm{A}_{\mathrm{c}}\right)$ is divided into five levels: very low $(<500)$, low (500-1500), moderate (1500-3000), high (3000-5000), and very high (>5000) (unit: $\mathrm{tha}^{-1} \mathrm{y}^{-1}$ ).

\subsubsection{Crop and Management Factor (C)}

The $\mathrm{C}$ factor has a high sensitivity to natural and human activities and plays a significant role in estimating water erosion $[35,36]$. In this study, we adopted six methods to estimate the $C$ factor and then selected four kinds of $C$ methods to assess soil retention service. In the $\mathrm{C} 1$ method, the land use and cover types originally categorized by the USGS global ecosystems legend are reclassified into 8 types based on their similarities, and then the average value of the $C$ factor is given to each land cover type in Table 2. Additionally, when select the better $C$ factor methods for this area, this study selected four land cover types (agricultural, forest/shrub, grassland and mixture-shrub land/sparse vegetation) from which to extract the $C$ factors, since their $C$ factor values were clearly different in the different land cover types according to the rules. In the C2 method, the NDVI is based on the NOAA Advanced Very High-Resolution Radiometer (AVHRR); thus, $\alpha=2$, and $\beta=1$. In the C3-C5 methods, only the $\mathrm{C}$ factor must be estimated according to the formulas. In the $\mathrm{C} 6$ method, fc represents the vegetation coverage (\%), which is obtained based on the NDVI. When the fc is greater than $78.3 \%$, $\mathrm{C}=1$; when the $\mathrm{fc}_{\mathrm{c}}$ is less than $0.1, \mathrm{C}=0$; and when the $\mathrm{fc}$ is between 0 and $78.3 \%, \mathrm{C}$ is calculated by the C6 formula. The six methods are shown as follows in Table 2. 
Table 2. Cover management factor ( $C$ factor) estimation methods.

\begin{tabular}{ccc}
\hline \multicolumn{1}{c}{ Method } & Region & Source \\
\hline $\begin{array}{c}\text { C1: Agriculture area (0.65), forest/shrub (0.01), grassland } \\
(0.15), \text { wetland }(0.56), \text { built-up area (1), water/drainage } \\
(0.01), \text { barren area }(0.28), \text { mixture }(0.40)\end{array}$ & Global & {$[34]$} \\
$\mathrm{C} 2=\mathrm{e}^{[(-\alpha) \times \mathrm{NDVI} /(\beta-\mathrm{NDVI})]}$ & Europe & {$[37,38]$} \\
$\mathrm{C} 3=[(1-\mathrm{NDVI}) / 2]^{(1+\mathrm{NDVI})}$ & Taiwan's Small Watershed & {$[39,40]$} \\
$\mathrm{C} 4=0.431-0.805 \times \mathrm{NDVI}$ & Southern France & {$[41]$} \\
$\mathrm{C} 5=1.02-1.21 \times \mathrm{NDVI}$ & Istanbul, Turkey & {$[42]$} \\
$\mathrm{C} 6=0.6508-0.3436 \operatorname{lgfc}$ & Three Gorges Basin & {$[43]$} \\
\hline
\end{tabular}

Notes: $f_{c}$ represents vegetation coverage $(\%) ; \mathrm{fc}=\frac{\text { NDVI-NDVImin }}{\text { NDVImax-NDVImin }} ; \alpha=2 ; \beta=1$.

\subsubsection{Erosivity Factor (R)}

The $\mathrm{R}$ factor was originally computed for the total storm energy (E) times the maximum $30 \mathrm{~min}$ intensity (I30), or EI30, and was expressed as the rainfall erosion index, which can reflect the impact of potential of rainstorms on water erosion [19,44]. We obtained the average annual rainfall erosivity at 86 weather stations nationwide from 1982 to 2010 to obtain a raster layer of the rainfall that was interpolated with the inverse distance to a power method. Then, the annual rainfall erosivity was calculated using the Richardson model based on the average annual rainfall, which is expressed in Equation (4) [28].

$$
\mathrm{R}=0.335 \mathrm{P}^{1.18}
$$

In Equation (4), $R$ represents the yearly rainfall erosivity, and $P$ represents the average annual precipitation $(\mathrm{mm})$.

\subsubsection{Topographic Factor (LS)}

The topographic factor reflects the impact of the water erosion slope length (L) and steepness (S) on water erosion. The LS factors are calculated by the slope, and the slopes are extracted from the DEM. The slope length factor is the water erosion normalized to the $22.13 \mathrm{~m}$ long slope in the RUSLE/USLE and is expressed as Equation (5), in which the slope exponent, $\mathrm{m}$, is $0.2,0.3,0.4$, and 0.5 for different increasing slope gradients [29]. The steepness is the water erosion normalized to the slope value of 5.12, and this study applied different formulas to calculate the steepness according to the different slope ranges; the steepness was calculated according to Liu (1994) [30] when the slope was more than $10^{\circ}$ and otherwise was calculated according to McCool (1987) [31]. The LS equations are as follows:

$$
\begin{gathered}
\mathrm{L}=\left(\frac{\varphi}{22.1}\right)^{\mathrm{m}} \\
\mathrm{m}=\left\{\begin{array}{c}
0.2, \theta \leq 1^{\circ} \\
0.3,1^{\circ}<\theta \leq 3^{\circ} \\
0.4,3^{\circ}<\theta \leq 5^{\circ} \\
0.5, \theta>5^{\circ}
\end{array}\right. \\
\mathrm{S}=\left\{\begin{array}{c}
10.8 \sin \theta+0.036, \theta<5^{\circ} \\
16.8 \sin \theta-0.5,5^{\circ} \leq \theta<10^{\circ} \\
21.9 \sin \theta-0.96, \theta \geq 10^{\circ}
\end{array}\right.
\end{gathered}
$$

In Equations (5)-(7), $\varphi$ is the noncumulative slope length ( $\mathrm{m}), \mathrm{m}$ is the slope length exponent, and $\theta$ is the slope angle. 


\subsubsection{Erodibility Factor (K)}

The soil erodibility factor is the rate of erosion per unit erosion index from a standard plot, which is a quantitative description of the inherent erodibility of a particular soil [45]. This study area uses the EPIC [32] model to estimate the soil erodibility factor based on the soil properties, and the equation is as follows:

$$
\begin{gathered}
\mathrm{K}=\frac{1}{7.6}\left\{0.2+0.3 \exp \left[0.0256 \mathrm{SAN}\left(1-\frac{\mathrm{SIL}}{100}\right)\right]\right\}\left(\frac{\mathrm{SIL}}{\mathrm{CLA}+\mathrm{SIL}}\right)^{0.3} \\
\times\left(1.0-\frac{0.25}{\mathrm{C}+\exp (3.72-2.95 \mathrm{C})}\right)\left(1.0-\frac{0.7 \mathrm{SN}}{\mathrm{SN}+\exp (22.9 \mathrm{SN}-5.51)}\right)
\end{gathered}
$$

In Equation (8), SN = 1-SAN/100, and SAN, SIL, CLA and C are the contents of sand, silt, clay and organic matter, respectively, in percentages.

\subsection{Linear Regression}

The Theil-Sen (TS) estimator uses a linear model to estimate the slope of the trend, and the Mann-Kendall (MK) statistical test is used to quantify the significance of the trends in a time series [46,47]; this latter test has been widely performed as the nonparametric trend analysis method to determine significant differences in remote sensing vegetation monitoring. The TS-MK only requires that the data are independent and that outlier effects can be eliminated regardless of the distribution sequence. Therefore, this study estimates the trend of soil retention service with the TS-MK method as follows [48,49]:

$$
\begin{gathered}
\text { slope = Median }\left(\frac{A_{c_{j}}-A_{c_{i}}}{t_{j}-t_{i}}\right) S=\sum_{i=1}^{n-1} \sum_{j=i+1}^{n} \operatorname{sign}\left(A_{c_{i}}-A_{c_{j}}\right) \operatorname{Var}(S)=\frac{n(n-1)(2 n+5)}{18} \\
\operatorname{sign}\left(A_{c_{i}}-A_{\mathcal{C}_{j}}\right)=\left\{\begin{array}{cl}
1 & \text { if } \quad A_{c_{i}}-A_{c_{j}}<0 \\
0 & \text { if } \quad A_{c_{i}}-A_{c_{j}}=0 \\
-1 & \text { if } \quad A_{c_{i}}-A_{c_{j}}>0
\end{array}\right. \\
Z=\left\{\begin{array}{cl}
\frac{S-1}{\sqrt{\operatorname{Var}(S)}} & \text { for } S>0 \\
0 & \text { for } S=0 \\
\frac{S+1}{\sqrt{\operatorname{Var}(S)}} & \text { for } S<0
\end{array}\right.
\end{gathered}
$$

In Equation (9), $A_{c_{i}}$ and $A_{c_{j}}$ are the soil retention service values of the area in years $i$ and $j$, respectively, and $\mathrm{n}$ represents the length of time based on S. A slope $>0$ represents water erosion restoration, and a slope $<0$ represents water erosion degradation. Additionally, $t_{i}$ and $t_{j}$ are the year numbers. If $|\mathrm{Z}|>1.64$, then the trend is significant.

\section{Results}

\subsection{Selection of C Factor}

A comparison of methods C1-C6 is shown in Figures 2 and 3, which contain the soil retention service, water erosion and $C$ factor values. The calculation results for soil retention service and water erosion using the 2013 data are shown in Figure 4. The water erosion and soil retention service values for the Nile River Basin in 2013 based on the six methods were shown in Table 3. The $C$ factor value differences for the four land cover types are shown in Figure 3. In the C1-C4 methods, the values of soil retention service are all approximately $1000\left(\mathrm{t} \mathrm{ha}^{-1} \mathrm{y}^{-1}\right)$, and the values of water erosion are less than $250\left(\mathrm{t} \mathrm{ha}^{-1} \mathrm{y}^{-1}\right)$, between the maximum $515.56\left(\mathrm{t} \mathrm{ha}^{-1} \mathrm{y}^{-1}\right)$ and the minimum $224.42\left(\mathrm{t} \mathrm{ha}^{-1} \mathrm{y}^{-1}\right)$ values. In addition, the value of the $C$ factor is obviously different for the four land cover types in the C1-C4 methods. The C5 method has C factor values of $0.72,0.66,0.86$, and 0.77 for the agricultural, forest/shrub, grassland and mixture types of land cover, respectively, which are difficult to distinguish; 
the C6 method has water erosion and soil retention service values of 1161.96 and $285.21\left(\mathrm{t} \mathrm{ha}^{-1} \mathrm{y}^{-1}\right)$, respectively, where the value of the water erosion is too small and the value of soil retention service is too large and are thus not in accordance with the rules. Thus, the C5-C6 methods are difficult to use to estimate soil retention service in the Nile River Basin. Therefore, the combination of the results presented in Figures 3 and 4 shows that methods C1-C4 used in this study are reasonable, whereas methods C5-C6 are not appropriate for this study. Therefore, this study selected methods C1-C4 to estimate the soil retention services in the Nile River Basin.

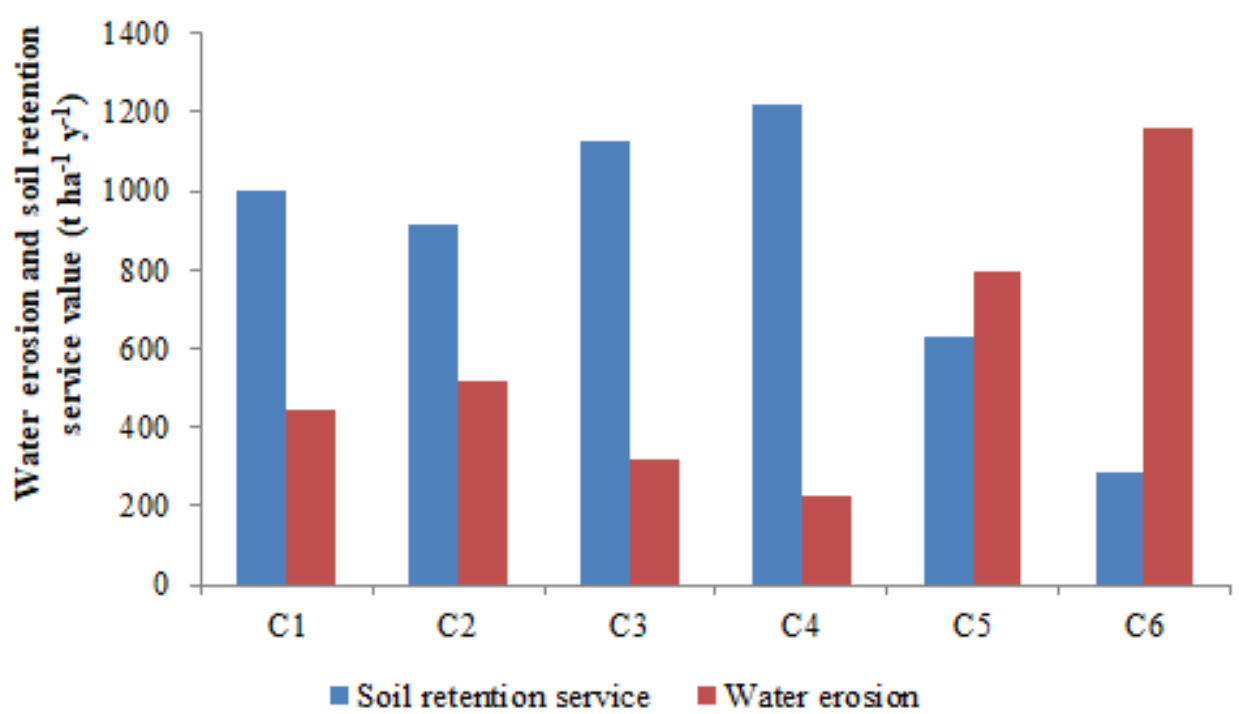

Figure 2. Water erosion and soil retention service values based on methods C1-C6 (13 years). C1-C6 represent the six $\mathrm{C}$ factor estimation methods shown in Table 2.

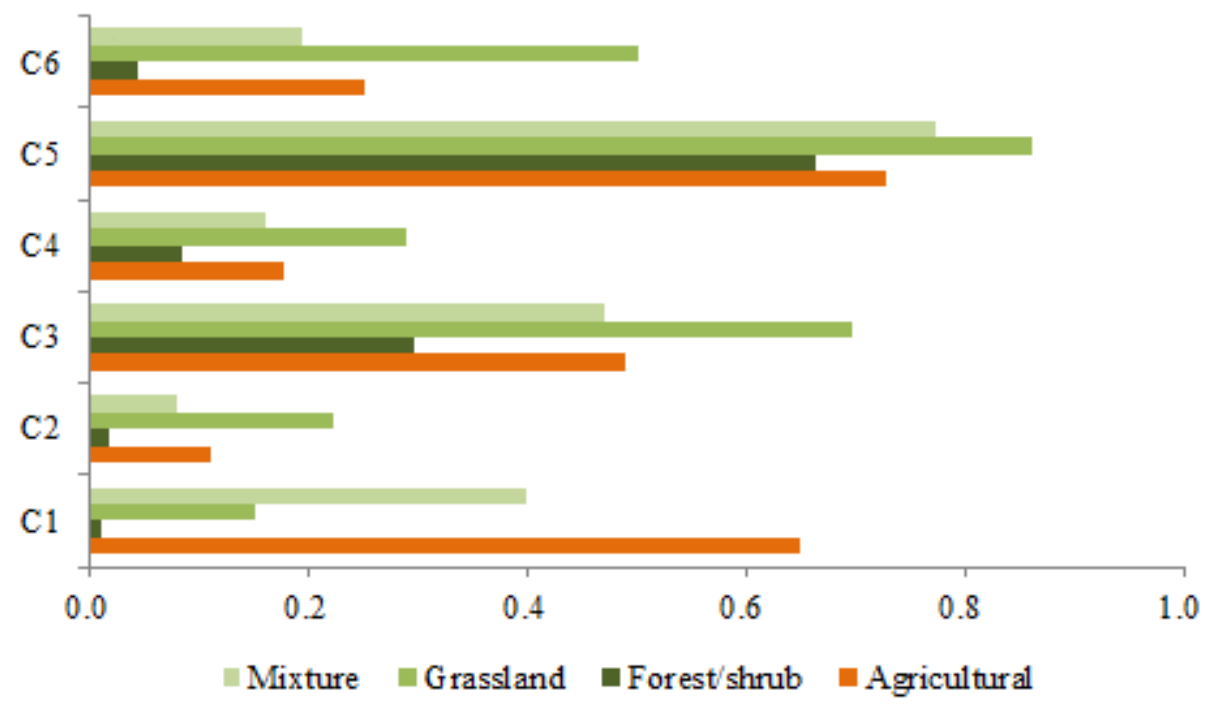

Figure 3. Comparison of the $\mathrm{C}$ factors $(\mathrm{C} 1-\mathrm{C} 6)$ obtained for the different land cover types. C1-C6 represent the six $\mathrm{C}$ factor estimation methods shown in Table 2. 


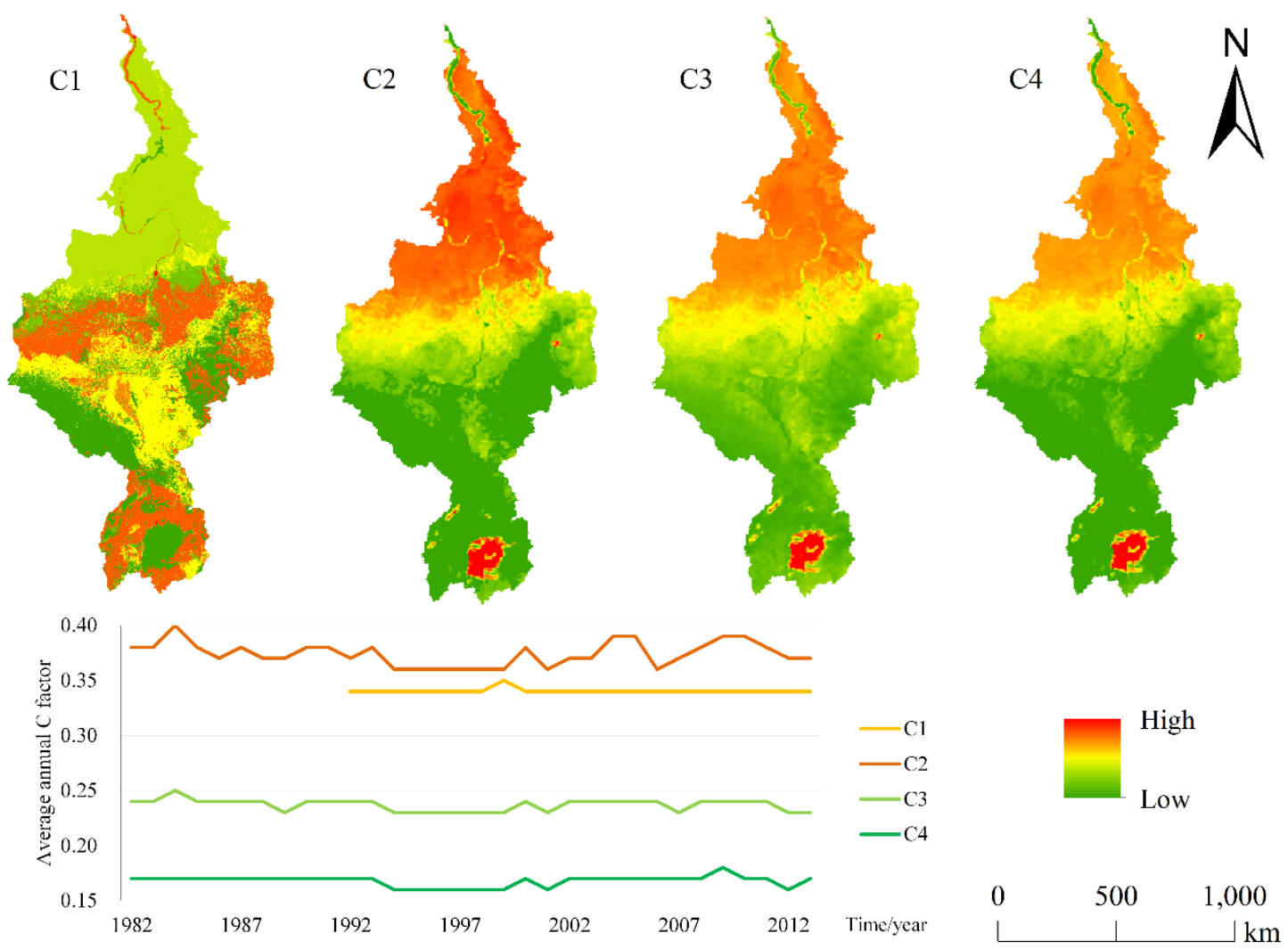

Figure 4. Spatiotemporal characteristic map of the average annual C factor (C1-C4) from 1982 to 2013. C1-C4 represent the four C factor estimation methods shown in Table 2.

Table 3. Water erosion and soil retention service based on six $\mathrm{C}$ factor methods in $2013\left(\mathrm{t} \mathrm{ha}^{-1} \mathrm{y}^{-1}\right)$.

\begin{tabular}{ccccccc}
\hline Six C Factor Methods & C1 & C2 & C3 & C4 & C5 & C6 \\
\hline Water erosion & 442.86 & 515.56 & 317.53 & 224.42 & 795.03 & 1161.96 \\
\hline Soil retention service & 1000.53 & 916.7 & 1122.91 & 1219.40 & 631.57 & 285.21 \\
\hline
\end{tabular}

\subsection{Change Tendency of the C Factor}

After mapping the average annual values of the $\mathrm{C}$ factor based on the $\mathrm{C} 1-\mathrm{C} 4$ methods, both spatial and temporal differences appeared (Figure 4). The $\mathrm{C} 1$ method shows spatial differences according to the land cover types and the $\mathrm{C} 2-\mathrm{C} 4$ methods, according to the extent of greenness. $\mathrm{C} 1$ shows a clear spatial difference according to the different land cover types, and $\mathrm{C} 2-\mathrm{C} 4$ show increasing values from south to north. Specifically, in the $\mathrm{C} 1$ method, the $\mathrm{C} 1$ distribution shows high values in the agriculture, wetland and built-up areas and low values in forest/shrub, water/drainage and grassland areas, which have high values in the center and south of the study area and low values in the southwest area. Compared to $\mathrm{C} 1, \mathrm{C} 2-\mathrm{C} 4$ show no significant differences in the land cover types; we can only see a rough spatial distribution from the direction. Combining the $\mathrm{C} 1$ method and $\mathrm{C} 2-\mathrm{C} 4, \mathrm{C} 1$ has a low value in Egypt, the southwest of Sudan and the center of Uganda, whereas C2-C4 has a low value in Sudan and around Uganda and Ethiopia. C1 shows a high value in northeast Ethiopia, the north of Sudan and around Uganda, whereas a higher value is evident in Egypt and the center of Uganda. In conclusion, the spatial distribution difference in the average annual $C$ factor is mainly in Egypt and Uganda. From a temporal perspective, the tendency of the average annual $C$ factor was similar in $\mathrm{C} 1-\mathrm{C} 4$, although some fluctuations around the mean were noted; however, the average annual $\mathrm{C}$ factor values obtained with $\mathrm{C} 1-\mathrm{C} 4$ were different $(0.34,0.37,0.23$, and 0.17 , respectively). 


\subsection{Change Tendency of the Soil Retention Service}

The average annual soil retention service calculated by the RUSLE model and based on the C1-C4 methods showed obvious spatiotemporal differences (Figure 5). On the whole, A1-A4 showed higher values in the southwest and east and lower values in the central and northern parts of this study area. The soil retention service in A1 yielded a higher soil retention service in the forest/shrub areas and a lower soil retention service in other land cover types. The spatial distributions of moderate and high soil retention service are consistent in A2-A4; however, A2 is different from A3-A4 in the distribution of low soil retention service. The average annual actual water erosion based on the same potential water erosion was $445.74,524.12,322.50$, and $227.21 \mathrm{tha}^{-1} \mathrm{y}^{-1}$, and the potential water erosion was $1441.78 \mathrm{t} \mathrm{ha}^{-1} \mathrm{y}^{-1}$. There was an area of approximately $2.12 \times 10^{6}-2.45 \times 10^{6} \mathrm{~km}^{2}$ with a very low and low soil retention service, which accounts for $70.12-80.86 \%$ of this area. An area of approximately $2.67 \times 10^{5}-3.79 \times 10^{5} \mathrm{~km}^{2}$ had a high and very high soil retention service, which accounts for $8.80-12.51 \%$ of this area. From a regional perspective, the southwest of Sudan and the Ethiopia area have a higher soil retention service, and central Sudan and northern Egypt show a lower soil retention service. In view of the temporal tendency, the tendencies of the average annual soil retention service were similar in A1-A4, although some fluctuations around the mean were noted; however, the average annual soil retention service values shown in A1-A4 were different (1020.22, $934.08,1139.76,1240.56\left(\mathrm{t} \mathrm{ha}^{-1} \mathrm{y}^{-1}\right)$, respectively). In conclusion, the $\mathrm{A} 2$ soil retention service was less than the A1, A3 and A4 soil retention service, and the A4 soil retention service was more than the A1-A3 soil retention service. Thus, the change in the range of the soil retention service was 934.08-1240.56 ( ha $\left.^{-1} \mathrm{y}^{-1}\right)$.
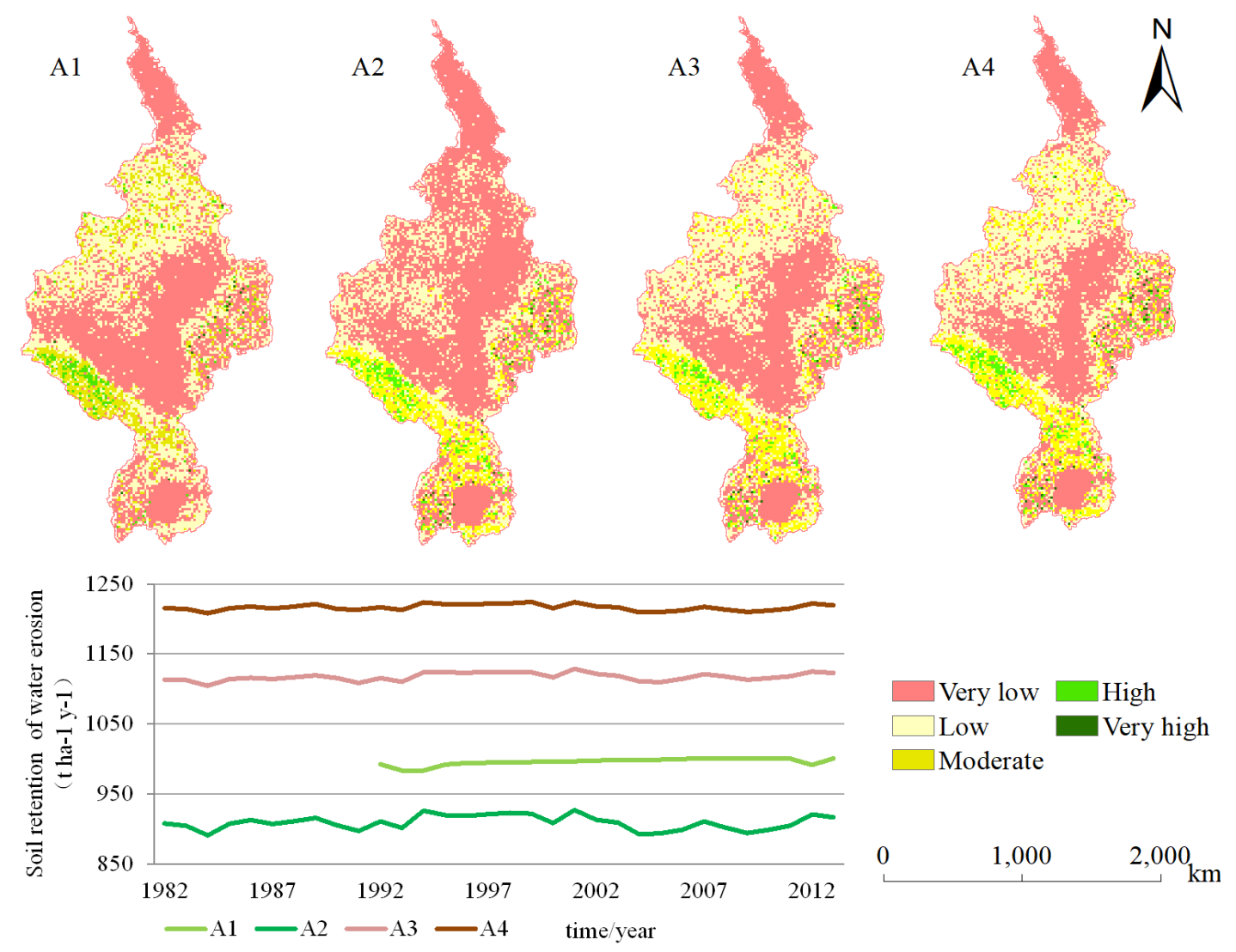

Figure 5. Spatial distribution of the average annual soil retention service and temporal tendency of the average annual soil retention based on four vegetation cover types and management factors (1982-2013). A1, average annual soil retention service based on C1 (1992-2013); A2, average annual soil retention service based on C2 (1982-2013); A3, average annual soil retention service based on C3 (1982-2013); A4, average annual soil retention service based on C4 (1982-2013). 


\subsection{Change Proportion of the Soil Retention Service}

The pixel proportion of tendency shows the spatial distributions of soil retention service change (Figure 6). In Figure 6a, the pixels representing significant change only account for $1.62 \%$ of this area, with an area of $5.19 \times 10^{4} \mathrm{~km}^{2}$. Because the map was calculated based on the land cover type, this method also estimates the proportion of vegetation, for example, agriculture (26.65\%), forest and shrub $(16.46 \%)$, grassland $(6.95 \%)$, and mixed vegetation $(20.18 \%)$. It is obvious that the pixels representing significant change are distributed in the center of this study area. In Figure $6 \mathrm{~b}-\mathrm{d}$, which are calculated based on the A2-A4 in Figure 5, the pixels representing a significant decrease or decrease account for $9.95 \%, 3.17 \%$, and $3.77 \%$ of this area, with areas of $3.17 \times 10^{5}, 9.94 \times 10^{4}$, and $3.77 \times 10^{5} \mathrm{~km}^{2}$, respectively. At the same time, the pixels representing significant increases or increases account for $3.77 \%, 2.37 \%$, and $3.02 \%$ of this area, with areas of $1.18 \times 10^{5}, 7.42 \times 10^{4}$, and $9.46 \times 10^{4} \mathrm{~km}^{2}$, respectively. From a regional perspective, the spatial distribution is obviously different among Figure 6a-d. Figure 6a shows the area of significant change at the junction of Sudan and Ethiopia. Figure 6b shows the areas of significant increases in Egypt and decreases in the southeast of Sudan. Figure 6c shows most of the significant increase area, with only $2.42 \times 10^{4} \mathrm{~km}^{2}$ showing a tendency to increase and $5.20 \times 10^{4} \mathrm{~km}^{2}$ showing a tendency to significantly decrease. For Figure $6 \mathrm{~d}$, it is similar to Figure $6 \mathrm{c}$ in the spatial distribution. From Figure $6 a-d$, we can see that the area ranges of pixels representing the significant increase and decrease in soil retention service are $1.31 \times 10^{4}-1.94 \times 10^{5} \mathrm{~km}^{2}$ and $5.68 \times 10^{3}-$ $3.81 \times 10^{4} \mathrm{~km}^{2}$, respectively.
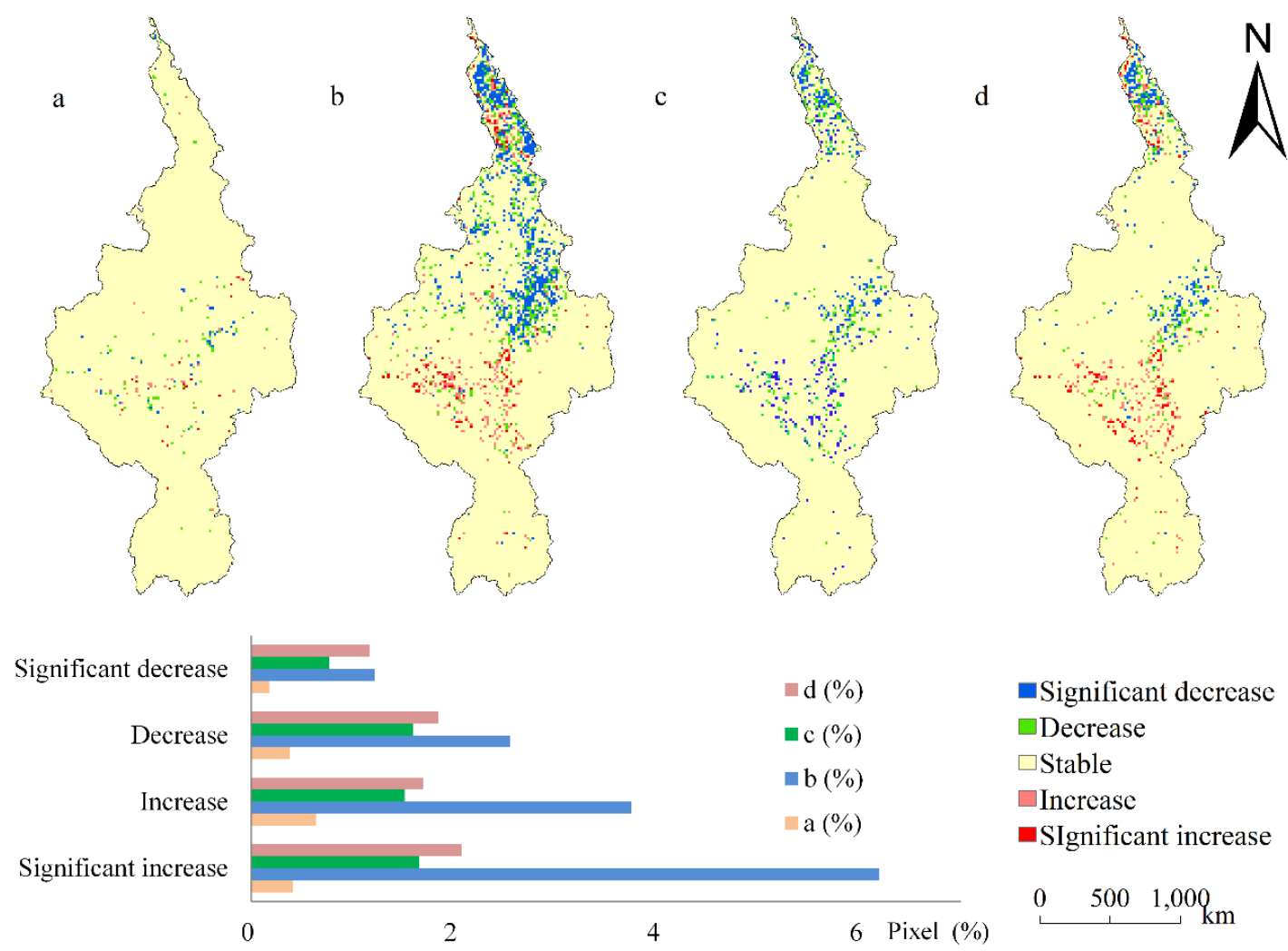

$\square$ Significant decrease
$\square$ Decrease
$\square$ Stable
$\square$ Increase
$\square$ SIgnificant increase

\begin{tabular}{lll}
0 & $500 \quad 1,000$ \\
\hdashline
\end{tabular}

Figure 6. Temporal tendency and area percentages of the average annual soil retention service based on methods A1-A4 (1982-2013). (a) A1, tendency of soil retention service based on C1 (1992-2013); (b) A2, tendency of soil retention service based on C2 (1982-2013); (c) A3, tendency of soil retention service based on C3 (1982-2013); (d) A4, tendency of soil retention service based on C4 (1982-2013); $(\mathrm{a} \%)$ area percentage based on $(\mathrm{a}) ;(\mathrm{b} \%)$ area percentage based on $(\mathrm{b}) ;(\mathrm{c} \%)$ area percentage based on $(\mathrm{c})$; $(\mathrm{d} \%)$ area percentage based on $(\mathrm{d})$. 
A soil retention service distribution with significant trends was found in the north and northeast areas. The significant increase area accounted for 13,067-194,016 $\mathrm{km}^{2}$, and the significant decrease area accounted for 5684-38,082 $\mathrm{km}^{2}$ and had a close relationship with the land cover type. An increasing tendency was observed from north to south. The temporal tendency showed a steady tendency from 1982 to 2013 in the Nile River Basin. In this study, soil retention service has only a slightly increasing tendency, which may indicate that this area still needs to take measures to prevent water erosion.

\section{Discussion}

\subsection{Evolution of C Factor Methods}

There are many methods of estimating the $C$ factor based on land use and the NDVI. The different estimation methods could reduce the error of the impact of $C$ factor overestimation or underestimation. Therefore, this study used six $\mathrm{C}$ factors to assess soil retention service, but the C5-C6 methods were not selected due to the errors in water erosion and the soil retention service and the similarity in the $\mathrm{C}$ factor values based on different land covers. The $\mathrm{C} 1$ method is commonly used on a large scale $[24,33]$. The $\mathrm{C} 2$ method has been used at the sub basin and sub country levels of this study [3,50,51]. For the C3-C4 methods, the water erosion and soil retention service values and the differences between the different features are reasonable for this study, and although the two methods are not used in this study, these methods can be used in future studies. When comparing the $\mathrm{C} 1-\mathrm{C} 4$ methods, the spatial distributions of the $\mathrm{C} 1$ and $\mathrm{C} 2-\mathrm{C} 4$ methods are clearly different because $\mathrm{C} 1$ is estimated by land cover types and $\mathrm{C} 2-\mathrm{C} 4$ are estimated by greenness. In the methods of $\mathrm{C} 2-\mathrm{C} 4$, the values of water and bare location are too high to estimate the $C$ factor, which may make the result questionable; however, this study mainly assessed the soil retention service rather than the $C$ factor, and the questionable result can be eliminated in the calculation process of the soil retention service. Thus, the $\mathrm{C} 2-\mathrm{C} 4$ methods are also reasonable for this study. In conclusion, the $C$ factor methods selected in this study are found to be reasonable.

\subsection{Evolution of Soil Retention Service}

The assessment results of the soil retention service were in accordance with the statistical information from the Nile River Basin in some selected sub basins and sub countries where water erosion information was available (Table 4). This study selected water erosion information based on the different methods and sources of the white and blue river basins. It is difficult to compare the results of the soil retention service given the differences in the model and scale; however, the reasonableness of the results can be judged. For example, this study selected the locations of the white and blue basins to compare the water erosion with previous studies. This study found higher water erosion in the white basins and lower values in the previous research; as for the blue basins, the results of this study were in accordance with previous results [3]. Considering the differences, although the previous research was based on models of similar environmental constraint envelopes (SECEs) and RUSLE, the previous research only estimated the $C$ factor with a method that was based on the NDVI and neglected the impact of land cover types. Therefore, this result can be regarded as an advancement that considers both the land cover types and the greenness at the same time. In addition, the water erosion ranges are from 227.21 to $524.12 \mathrm{t} \mathrm{ha}^{-1} \mathrm{y}^{-1}$ in this study, and this result is similar to the result of the Nile River Basin, which was extracted from the estimation of global water erosion [34]. Moreover, we collected statistical information about water erosion from some countries in this study, such as Uganda, Ethiopia, Sudan, Tanzania and Kenya (Table 4). Due to the lack of information on Egypt, we only collected statistics on the water erosion information for these five countries; the range was 350 to $371\left(\mathrm{t} \mathrm{ha}^{-1} \mathrm{y}^{-1}\right)$, which is similar to what we found in our study. Therefore, our research is in line with the public's perception. 
Table 4. Average water erosion for different regions in the Nile River Basin by different studies.

\begin{tabular}{ccc}
\hline Study Site & Water Erosion $\left(\mathbf{t ~ h a}^{-\mathbf{1}} \mathbf{y}^{\mathbf{- 1}}\right)$ & The Source of Article \\
\hline Nile River Basin & 417 & {$[34]$} \\
the Blue Volta & $75(\mathrm{NSL})$ & {$[3]$} \\
the White Volta & $28(\mathrm{NSL})$ & {$[3]$} \\
Ethiopia & 185 & {$[52]$} \\
Nyando catchment, Kenya & 90 & {$[53]$} \\
Uganda & 10 & {$[2]$} \\
Sudan & $21-48$ & {$[54]$} \\
Upper Blue Nile River & 27.5 & {$[55]$} \\
Tanzania & 10 & {$[52]$} \\
\hline
\end{tabular}

Note average net water erosion (NSL).

Nevertheless, the impacts of land cover types and greenness on the soil retention service differed (Table 5). Obviously, the forest and shrub areas have the highest capacity to conserve soil in A1-A4, whereas the water/drainage and wetland areas have the lowest. However, the comparison between the barren area and the agricultural area is more controversial because the soil retention service is higher in the barren area than in the agricultural area in $\mathrm{A} 1$, whereas $\mathrm{A} 2-\mathrm{A} 3$ provide the opposite result. Many factors can cause this phenomenon (e.g., human activities, rainfall erosivity or the methods); thus, this issue warrants further study. The grassland and mixture areas have a moderate level of soil retention service. Accordingly, the estimation results obtained with A1-A4 in this study remind researchers that many factors should be considered in the estimation of the soil retention service. In conclusion, this study evaluates the statistics on the changes in soil retention service by land cover types based on A1-A4, but we cannot analyze in detail how soil retention service changes according to the land cover types based on the greenness. Thus, further research is still needed.

Table 5. Area percentages of the land cover types and A1-A4 soil retention service.

\begin{tabular}{cccccc}
\hline Land Cover Types & Percentages of Areas (\%) & A1 (\%) & A2 (\%) & A3 (\%) & A4 (\%) \\
\hline Agriculture area & 26.67 & 10.32 & 16.55 & 14.76 & 14.70 \\
Forest/Shrub & 16.51 & 31.61 & 34.75 & 27.80 & 27.05 \\
Grassland & 6.95 & 11.13 & 7.74 & 9.66 & 9.88 \\
Wetland & 1.59 & 5.55 & 7.45 & 5.94 & 5.64 \\
Built-up area & 0.14 & 7.18 & 11.89 & 12.97 & 14.44 \\
Water/Drainage & 3.18 & 4.20 & 4.68 & 4.45 & 4.07 \\
Barren Area & 25.31 & 20.29 & 5.02 & 13.65 & 13.63 \\
Mixture & 19.65 & 9.71 & 11.91 & 10.76 & 10.60 \\
\hline
\end{tabular}

Note: methods A1-A4 represent the average annual soil retention service values obtained based on C1-C4.

\subsection{Uncertainties and Future Directions}

Although uncertainty analysis is not the key component of soil retention service research on a large scale, it is still necessary to further explore the uncertainty and to improve the accuracy. Therefore, this study explores the uncertainty from the data source and the effect of the driving factors.

With respect to the data source, the use of data in an evaluation of the soil retention service is still worth exploring. This study estimated the $C$ factor based on the NDVI and the land use and cover, in which the NDVI focused on the change in greenness and the land use and cover focused on the change in types. Thus, the spatial differences of the $C$ factor based on greenness and type are our foci. Of course, the temporal mapping of soil retention service comes at the cost of reduced accuracy. First, if we only explore the spatiotemporal characteristics of soil retention service after 2000 or 2010, the Moderate Resolution Imaging Spectroradiometer (MODIS) NDVI with a $1 \mathrm{~km}$ resolution can be applied in this study. However, the spatiotemporal characteristics are not obvious within a period of more than decade, so the GIMMS NDVI is regarded as a good choice when estimating soil retention 
service for a period of over thirty years. Although the land cover types were annually continuous in 1992 and lacked data from 1982-1991, generally speaking, large changes in land cover types are difficult to evaluate during a period of less than a decade; thus, these are the only and longest term land cover data from 1992 to 2013 that can be used to explore the impact of the types on the $C$ factor and soil retention service in this study.

From the effect of the driving factors, it is obvious that the distribution of the other factors for RUSLE changes is less uncertain than the crop and management $C$ factor. For the rainfall erosivity factor $\mathrm{R}$, which is calculated by the spatial interpolation of precipitation, the spatial interpolation can increase the uncertainty of the sample values. For the topographic factor LS, which is calculated according to slopes extracted by the $90 \mathrm{~m} \mathrm{DEM}$, it also increases the uncertainty of the accuracy of the soil retention service estimation. Because the value of the LS indicator would be largely reduced and distorted if the resolution of the elevation were coarser, when targeting a regional soil retention service estimation, a finer elevation resolution is recommended to calculate the LS indicator. For the erodibility factor $\mathrm{K}$, which is calculated by the soil properties, it also increases the uncertainty due to the difference in soil types. To derive the appropriate $\mathrm{P}$ factor, although there is little impact on soil retention service with a value of one, the uncertainty would decrease if the $\mathrm{P}$ factor could be calculated with an approach similar to the calculation of the $C$ factor.

With respect to the uncertainty analysis, it is important to make a careful judgment of the uncertainty factors when assessing soil retention service at a large scale. This study used four $C$ factor methods to assess soil retention service from land cover types and greenness. However, whether we can assess soil retention service based on land cover in the future would make a great contribution to future research on soil retention service. For example, if we could establish a scenario that could maintain the balance of soil retention service according to the greenness change for the land cover types (e.g., first build an ecological security pattern, then simulate land and climate changes based on the pattern, and finally estimate soil retention service in this pattern), it would receive widespread attention. Further explorations can take the hydrological regime in the catchment into account, as assessed by Jiang [56,57]. Ito (2007) estimated that the uncertainty about the vulnerability of soils would increase due to the loss of more organic matter and mineral nutrients [44], which is also a possible research direction. In summary, this research scenario simulation is worth advancing and can provide guidance for the management of future soil retention service and the prevention of water erosion.

\section{Conclusions}

Water erosion is a serious threat in the Nile River Basin, and detailed spatiotemporal information of soil retention service is required. This study mapped the changes of water erosion and soil retention service based on the $C$ factor variance estimated by land cover types and vegetation indices. The findings showed that, although the soil retention service has improved in recent years, water erosion is still at a relatively high level. In a summary, as a typical ecosystem service, the soil retention service is significant for human wellbeing and ecosystem health in the Nile River Basin. This study provides a reference for the selection of $C$ factor methods and evidence for the change in water erosion and soil retention service in the Nile River Basin. In future studies, in order to improve the limitations of the mapping and water erosion and soil retention service, both more accurate datasets and more effective algorithms can play an important role for improving the mapping accuracy. In addition, some human activities such as land management measures and economic investment should be taken into account.

Author Contributions: Conceptualization, W.Z. and Y.L.; methodology, H.L.; validation, H.L. and Y.L.; data curation, H.L.; writing —original draft preparation, H.L.; visualization, H.L.; supervision, W.Z. All authors have read and agreed to the published version of the manuscript.

Funding: This work was supported by the National Key Research and Development Program of China (No. 2017YFA0604704), the Strategic Priority Research Program of Chinese Academy of Sciences (XDA19030201), and Fundamental Research Funds for the Central Universities of China.

Conflicts of Interest: The authors declare no conflict of interest. 


\section{References}

1. Panagos, P.; Standardi, G.; Borrelli, P.; Lugato, E.; Montanarella, L.; Bosello, F. Cost of agricultural productivity loss due to water erosion in the European Union: From direct cost evaluation approaches to the use of macroeconomic models. Land Degrad. Dev. 2018, 29, 471-484. [CrossRef]

2. Karamage, F.; Zhang, C.; Ndayisaba, F.; Shao, H.; Kayiranga, A.; Fang, X.; Nahayo, L.; Nyesheja, E.M.; Tian, G. Extent of Cropland and Related Water erosion Risk in Rwanda. Sustainability 2016, 8, 609. [CrossRef]

3. Tamene, L.; Le, Q.B. Estimating water erosion in sub-Saharan Africa based on landscape similarity mapping and using the revised universal water erosion equation (RUSLE). Nutr. Cycl. Agroecosyst. 2015, 102, 17-31. [CrossRef]

4. Amdihun, A.; Gebremariam, E.; Rebelo, L.M.; Zeleke, G. Suitability and scenario modeling to support soil and water conservation interventions in the Blue Nile Basin, Ethiopia. Environ. Syst. Res. 2014, 3, 23. [CrossRef]

5. Mitri, G.; Nasrallah, G.; Gebrael, K.; Nassar, M.B.; Abou Dagher, M.; Nader, M.; Masri, N.; Choueiter, D. Assessing land degradation and identifying potential sustainable land management practices at the subnational level in Lebanon. Environ. Monit. Assess. 2019, 191, 567. [CrossRef]

6. Melaku, N.D.; Renschler, C.S.; Holzmann, H.; Strohmeler, S.; Bayu, W.; Zucca, C.; Zladat, F.; Klik, A. Prediction of soil and water conservation structure impacts on runoff and erosion processes using SWAT model in the northern Ethiopian highlands. J. Soils Sediments 2018, 18, 1743-1755. [CrossRef]

7. Xiao, Q.; Hu, D.; Xiao, Y. Assessing changes in soil retention service ecosystem services and causal factors in the Three Gorges Reservoir region of China. J. Clean. Prod. 2017, 163, S172-S180. [CrossRef]

8. Willemen, L.; Crossman, N.D.; Quatrini, S.; Egoh, B.; Kalaba, F.K.; Mbilinyi, B.; de Groot, R. Identifying ecosystem service hotspots for targeting land degradation neutrality investments in south-eastern Africa. J. Arid. Environ. 2018, 159, 75-86. [CrossRef]

9. Wadaey, A.A.; Ziadat, F. A Participatory GIS Approach to identify Critical Land Degradation Areas and Prioritize Soil retention service for Mountainous Olive Groves (Case Study). J. Mt. Sci.-Engl. 2014, 11, 782-791. [CrossRef]

10. Rao, E.; Ouyang, Z.Y.; Yu, X.X.; Xiao, Y. Spatial patterns and impacts of soil retention service service in China. Geomorphology 2014, 207, 64-70. [CrossRef]

11. Fernandez, C.; Vega, J.A.; Vieira, D.C.S. Assessing water erosion after fire and rehabilitation treatments in nw spain: Performance of RUSLE and revised Morgan-Morgan-Finney models. Land Degrad. Dev. 2010, 21, 58-67. [CrossRef]

12. Phinzi, K.; Ngetar, N.S. The assessment of water-borne erosion at catchment level using GIS-based RUSLE and remote sensing: A review. J. Soil Water Conserv. 2019, 7, 27-46. [CrossRef]

13. FAO-ITPS. Global soil status, processes and trends. In Status of the World's Soil Resources; Food and Agriculture Organization: Rome, Italy, 2015.

14. Jiang, C.; Zhang, H.Y.; Zhang, Z.D. Spatially explicit assessment of ecosystem services in China's Loess Plateau: Patterns, interactions, drivers, and implications. Glob. Planet. Chang. 2018, 161, 41-52. [CrossRef]

15. Jiang, C.; Zhang, H.Y.; Zhang, Z.D.; Wang, D.W. Model-based assessment water erosion by wind and water erosion in China's Loess Plateau: Dynamic change, conservation effectiveness, and strategies for sustainable restoration. Glob. Planet. Chang. 2019, 172, 396-413. [CrossRef]

16. Renard, K.G.; Foster, G.R.; Weesies, G.; Porter, J.P. RUSLE: Revised universal water erosion equation. J. Soil Water Conserv. 1991, 46, 30-33.

17. Taye, G.; Vanmaercke, M.; Poesen, J.; Wesemael, B.V.; Tesfaye, S.; Teka, D.; Nyssen, J.; Deckers, J.; Haregeweyn, N. Determining RUSLE P- and C-factors for stone bunds and trenches in rangeland and cropland, North Ethiopia. Land Degrad. Dev. 2017, 29, 812-824. [CrossRef]

18. Didone, E.J.; Gomes, M.J.P.; Merten, G.H. Quantifying water erosion and sediment yield in a catchment in southern Brazil and implications for land conservation. J. Soils Sediments 2015, 15, 2334-2346. [CrossRef]

19. Renard, K.G.; Foster, F.G.; Weesies, G.A.; Mc Cool, D.; Yoder, D. Predicting water erosion by water: A guide to conservation planning with the Revised Universal Soil Erosion Equation (RUSLE); Agricultural Handbook No. 703; United States Department of Agriculture: Washington, DC, USA, 1997. 
20. Lopez-Vicente, M.; Lana-Renault, N.; Garcia-Ruiz, J.M.; Navas, A. Assessing the potential effect of different land cover management practices on sediment yield from an abandoned farmland catchment in the Spanish Pyrenees. J. Soils Sediments 2011, 11, 1440-1455. [CrossRef]

21. Le Roux, J.J.; Morgenthal, T.L.; Malherbe, J.; Pretorius, D.J.; Sumner, P.D. Water erosion prediction at a national scale for South Africa. Water SA 2008, 34, 305-314. [CrossRef]

22. Deng, J.S.; Wang, K.; Deng, Y.H.; QI, G.J. PCA-based land-use change detection and analysis using multitemporal and multisensory satellite data. Int. J. Remote Sens. 2008, 29, 4823-4838. [CrossRef]

23. Chen, H.; Oguchi, T.; Wu, P. Assessment for water erosion by using a scheme of alterative sub-models based on the RUSLE in a Karst basin of Southwest China. J. Integr. Agric. 2017, 16, 377-388. [CrossRef]

24. Fu, B.J.; Zhao, W.W.; Chen, L.D.; Zhang, Q.J.; LV, Y.H.; Gulinck, H.; Poesen, J. Assessment of water erosion at large watershed scale using RUSLE and GIS: A case study the loess plateau of china. Land Degrad. Dev. 2005, 16, 73-85. [CrossRef]

25. Yang, J.; Wan, Z.Q.; Borjigin, S.; Zhang, D.; Yan, Y.L.; Chen, Y.L.; Gu, R.; Gao, Q.Z. Changing trends of NDVI and their responses to climatic variation in different types of grassland in inner Mongolia from 1982-2011. Sustainability 2019, 11, 3256. [CrossRef]

26. Vlek, P.L.G.; Le, Q.B.; Tamene, L. Assessment of land degradation, its possible causes and threat to food security in Sub-Saharan Africa. In Food Security and Soil Quality; Lal, R., Stewart, B.A., Eds.; CRC Press: Boca Raton, FL, USA, 2010; pp. 57-86.

27. Mengistu, D.T.; Sorteberg, A. Sensitivity of SWAT simulated streamflow to climatic changes within the Easter Nile River basin. Hydrol. Earth Syst. Sci. 2012, 16, 391-407. [CrossRef]

28. Elsenbeer, H.; Cassel, K.; Tinner, W. A daily rainfall erosivity model for Western Amazonia. J. Soil Water Conserv. 1993, 48, 439-444.

29. Liu, B.Y.; Nearing, M.A.; Shi, P.J.; Jia, Z.W. Slope Length effects on water erosion for steep slopes. Soil Sci. Soc. Am. J. 2000, 64, 1759. [CrossRef]

30. Liu, B.Y.; Nearing, M.A.; Risses, L.M. Slope gradient effects on water erosion for steep slopes. Trans. ASAE 1994, 37, 1835-1840. [CrossRef]

31. McCool, D.K.; Brown, L.C.; Foster, G.R.; Mutchler, C.K.; Meyer, L.D. Revised slope steepness factor for the Universal Water erosion Equation. Trans. ASAE 1987, 30, 1387-1396. [CrossRef]

32. Williams, J.R. The erosion-productivity impact calculator (EPIC) model: A case history. Philosophical transactions of the Royal Society of London Series. B-Biol. Sci. 1990, 329, 421-428.

33. Pham, T.N.; Yang, D.W.; Kanae, S.; Oki, T.; Musiake, K. Application of RUSLE Model on Global Water erosion Estimate. J. Hydraul. Eng. 2001, 45, 811-816. [CrossRef]

34. Yang, D.W.; Kanae, S.; Oki, T.; Koike, T.; Musiak, K. Global potential water erosion with reference to land use and climate changes. Hydrol. Process. 2003, 17, 2913-2928. [CrossRef]

35. Patil, R.J.; Sharma, S.K. Estimation of crop management factor (C) of universal water erosion equation for water erosion modeling using RS and GIS techniques in Shakker river watershed Chhindwara, Madhya Pradesh, India. JNKVV Res. J. 2013, 47, 111-115.

36. Chen, S.F.; Zha, X.; Bai, Y.H.; Wang, L.Y. Evaluation of water erosion vulnerability on the basis of exposure, sensitivity, and adaptive capacity: A case study in the Zhuxi watershed, Changting, Fujian Province, southern China. Catena 2019, 177, 57-69. [CrossRef]

37. Zhao, L.S.; Hou, R. Human causes of water erosion in rural karst environments: A case study of Guizhou, China. Sci. Rep. 2019, 9, 1-11.

38. Van der Knijff, J.; Jones, R.; Montanarella, L. Soil erosion risk assessment in Europe; European Soil Bureau, Joint Research Centre, European Commission and Space Applications Institute: Brussel, Belgium, 2000; pp. 17-19.

39. Lin, C.Y.; Lin, W.T.; Chou, W.C. Water erosion prediction and sediment yield estimation: The Taiwan experience. Soil. Tillage Res. 2002, 68, 143-152. [CrossRef]

40. Lin, W.T.; Lin, C.Y.; Chou, W.C. Assessment of vegetation recovery and water erosion at landslides caused by a calastrophic earthquake: A case study in Central Taiwan. Ecol. Eng. 2006, 28, 79-89. [CrossRef]

41. De Jong, S.M. Derivation of vegetation variables from a Landsat TM image for modelling water erosion. Earth Surf. Process. Landf. 1994, 19, 165-178. [CrossRef]

42. Karaburu, A. Estimation of $C$ factor for soil erosion modeling using NDVI in Buyukcekmece watershed. Ozean J. Appl. Sci. 2016, 3, 77-85. 
43. Cai, C.F.; Ding, S.W.; Shi, Z.H.; Hu, A.L.; Zhang, G.Y. Study of applying USLE and geographical information system IDRISI to predict water erosion in small watershed. J. Soil Water Conserv. 2000, 14, 19-24.

44. Ito, A. Simulated impacts of climate and land-cover change on water erosion and implication for the carbon cycle, 1901 to 2100. Geophys. Res. Lett. 2007, 34. [CrossRef]

45. Symeonakis, E.; Drake, N. Monitoring Desertification and land degradation over sub-Saharan Africa. Int. J. Remote Sens. 2004, 25, 573-592. [CrossRef]

46. Silva, R.M.; Celso, A.G.S.; Moreira, M.; Corte-Real, J.; Silva, V.C.L.; Medeiros, I.C. Rainfall and river flow trends using Mann-Kendall and Sen's slope estimator statistical tests in the Cobres River basin. Nat. Hazards 2015, 77, 1205-1221. [CrossRef]

47. Rahman, A.; Muhammad, D. Spatio-statistical analysis of temperature fluctuation using Mann-Kendall and Sen's slope approach. Clim. Dyn. 2017, 48, 783-797. [CrossRef]

48. Kendall, M.G. Ank Correlation Methods; Griffin: London, UK, 1975.

49. Sen, P.K. Estimates of the regression coefficient based on Kendall's tau. J. Am. Stat. Assoc. 1989, 63, 1379-1389. [CrossRef]

50. Taddese, G. Land degradation: A challenge to Ethiopia. Environ. Manag. 2001, 27, 815-824. [CrossRef] [PubMed]

51. Cerretelli, S.L.; Poggio, A.; Gimona, G.; Yakob, S.; Boke, M.; Habte, M.; Coull, A. Spatial assessment of land degradation through key ecosystem services: The role of globally available data. Sci. Total Environ. 2018, 628, 539-555. [CrossRef] [PubMed]

52. Symeonakis, E.; Drake, N. 10-Daily Water erosion modeling over sub-Saharan Africa. Environ. Monit. Assess. 2010, 161, 369-387. [CrossRef]

53. Shepherd, K.; Walsh, M.; Mugo, F.; Ong, C.; Svan-Hansen, T.; Swallow, B.; Awiti, A.; Hai, M.; Nyantika, D.; Ombalo, D.; et al. Improved Land Management in the Lake Victoria Basin: Linking Land and Lake, Research Land Extension, Catchment and Lake Basin; Final Technical Report, Start-up Phase; ICRAF: Nairobi, Kenya, 2000.

54. Shamseddln, M.A.; Mohamed, M.Y.; Hilmi, H.S.; Eshag, H.M. Assessing water erosion hazards using the Universal Water erosion Equation: A case study of central Sudan. Int. J. Soil Crop. Sci. 2014, 2, 077-085.

55. Haregeweyn, H.; Tsunekawa, A.; Poesen, J.; Tsubo, M.; Meshesha, D.T.; Fenta, A.A.; Nyssen, J.; Adgo, J. Comprehensive assessment of water erosion risk for better land use planning in river basins: Case study of the Upper Blue Nile River. Sci. Total Environ. 2017, 574, 95-108. [CrossRef]

56. Jiang, C.; Zhang, L.B.; Li, D.Q.; Li, F. Water Discharge and Sediment Load Changes in China: Change Patterns, Causes, and Implications. Water 2015, 7, 5849-5875. [CrossRef]

57. Jiang, C.; Wang, J.; Li, C.Y.; Wang, X.C.; Wang, D.W. Understanding the hydropower exploitation's hydrological impacts through a Len of change in flow-sediment relationship: A case study in the Han River Basin, China. Ecol. Eng. 2019, 129, 82-96. [CrossRef] 